\title{
Robust and Low-Cost Light Shaping
}

Bañas, Andrew Rafael; Palima, Darwin; Glückstad, Jesper

Published in:

Optics \& Photonics News

Link to article, DOI:

10.1364/OPN.23.12.000050

Publication date:

2012

Document Version

Publisher's PDF, also known as Version of record

Link back to DTU Orbit

Citation (APA):

Bañas, A. R., Palima, D., \& Glückstad, J. (2012). Robust and Low-Cost Light Shaping. Optics \& Photonics News, 23(12), 50. https://doi.org/10.1364/OPN.23.12.000050

\section{General rights}

Copyright and moral rights for the publications made accessible in the public portal are retained by the authors and/or other copyright owners and it is a condition of accessing publications that users recognise and abide by the legal requirements associated with these rights.

- Users may download and print one copy of any publication from the public portal for the purpose of private study or research.

- You may not further distribute the material or use it for any profit-making activity or commercial gain

- You may freely distribute the URL identifying the publication in the public portal

If you believe that this document breaches copyright please contact us providing details, and we will remove access to the work immediately and investigate your claim. 


\section{Robust and Low-Cost Light Shaping}

$\mathrm{P}$ hase-only spatial light modulation is used to shape light in microscopy, micromanipulation, microfabrication and biophotonics. One application of phase modulation is the creation of dynamic optical traps for directly controlling the motion of microscopic particles by using programmable spatial light modulators (SLMs). ${ }^{1,2}$ Similarly, light can be phase-sculpted to match and target biological material or trigger localized biochemical reactions. ${ }^{3}$ Despite its versatility, phase-only spatial light modulation requires pricey SLMs, which limit its use in photonics research. However, consumer projectors are much more affordable. Researchers have started to explore using projectors based on liquid-crystal-onsilicon (LCoS) as binary-only phase modulators by replacing the incoherent light source with a laser of appropriate polarization.

Using two modified pocket pico-projectors, we have demonstrated beam shaping based on matched filtering generalized phase contrast (mGPC). ${ }^{4}$ One projector is encoded with dynamic correlation target phase patterns that are directly mapped into intensity spikes. The other projector acts as a tunable matched filter combining GPC and phase-only correlation.

Although these modified projectors can be operated as binary holograms, mGPC offers advantages similar to GPC. Because mGPC is based on a $4 f$ geometry, it does not have a strong undiffracted zero-order light that would disturb the sample plane or waste optical energy. The fast encoding into the LCoS by copying and translating a basis correlation target pattern enables real-time reconfigurability of multiple intensity spots without the need of high-end resources. Such simplicity also prevents the formation of ghost orders, speckles and spurious phase variations.

Therefore, mGPC-generated light propagates in a well-defined manner and is useful for axially extended applications like active optical sorting or counter-propagating traps..$^{2,5}$ Since (a)

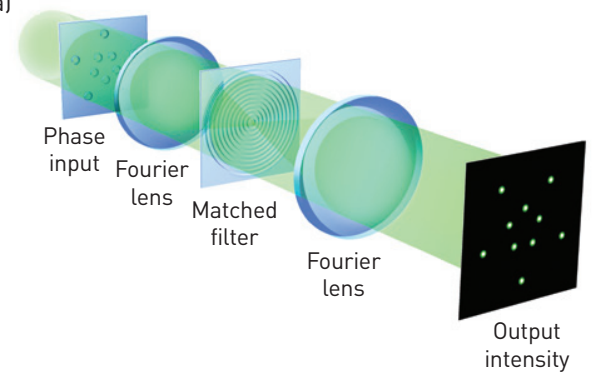

(c)

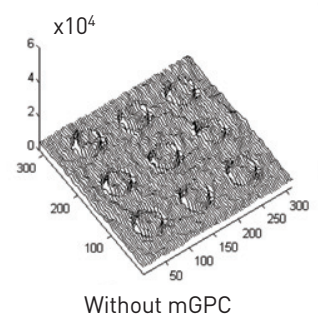

(d)

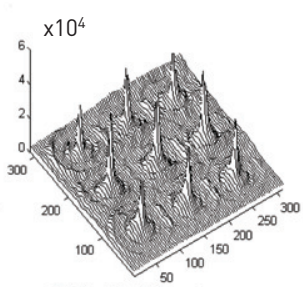

mGPC with disk patterns (b)

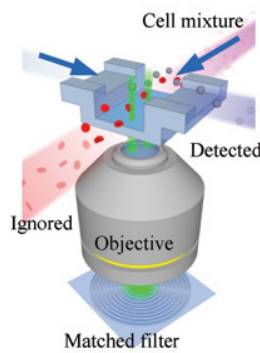

(e)

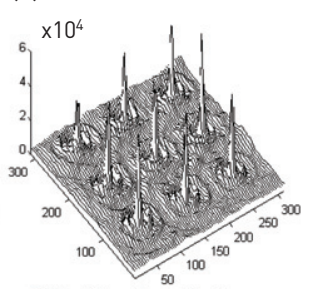

mGPC with optimized patterns

(a) An mGPC is used to generate intense light for particle sorting. (b) Intensity profiles are generated using two LCoS pico-projectors as binary phase input and matched phase filter: (c) without the filter, (d) using phase disks as the input phase pattern and (e) using an optimized binary input phase and matched filter.

mGPC borrows features of phase-only optical correlation, the generated output spikes are significantly stronger than the background noise caused by surface imperfections in consumer LCoS devices.

Because many research applications require a specific fixed beam size (e.g., manipulation of microscopic tools or cells, programmable microscopy or microfabrication), a fixed fabricated matched filter can be used to increase overall light efficiency. Replacing the second projector would also make the beam-shaping system more compact. The correlation pattern and filter can be optimized to increase the space bandwidth, thus producing narrower, more intense output spikes. ${ }^{4}$ OPN the video that accompanies this article.

\section{Researchers}

Andrew R. Bañas, Darwin Palima and Jesper Glückstad (jesper.gluckstada fotonik.dtu.dk)

Technical University of Denmark in Kongens Lyngby.

\section{References}

1. D. Palima et al. Opt. Express 20, 2004 (2012).

2. P. Rodrigo et al. Opt. Express 17, 6578 (2009).

3. E. Papagiakoumou et al. Nat. Methods 7, 848 (2010).

4. A. Bañas et al. Opt. Express 20, 9705 (2012).

5. I. Perch-Nielsen et al. J. Opt. A-Pure Appl. Op. 11, 034013 (2009). 